Asynchronous Online Learning Experiences of Students in Pandemic Process: Facilities, Challenges, Suggestions

Turkish Online Journal of Qualitative Inquiry (TOJQI)

Volume 12, Issue 2, April 2021: 173-200

DOI: $10.17569 /$ tojqi.767378

Research Article

\title{
Asynchronous Online Learning Experiences of Students in Pandemic Process: Facilities, Challenges, Suggestions ${ }^{1}$
}

\author{
Mücahit Öztürk ${ }^{2}$
}

\begin{abstract}
This study examined students' experiences in an asynchronous online learning environment. Students evaluated the asynchronous online learning environment in terms of interaction, feedback, academic and technical support, active learning and assessment. The study, which was carried out with a qualitative research approach, was conducted with 28 students studying in faculty of education. During the pandemic, students continued all their courses for 9 weeks with asynchronous distance education. At the end of the semester, the interview form was sent to the students via e-mail. At the end of the study, it can be said that in the process of asynchronous online learning, students experience a lack of face-to-face interaction even if they do not have communication problems with the instructor. Students were able to get support when they needed it. However, they had problems getting instant feedback. It was seen that students had the opportunity to learn flexibly without time and space, to learn independently by doing unlimited repetitions at their own pace and to plan their own learning process. However, it was revealed that they could not do group work with their friends and felt socially isolated. Students objected to the evaluation of their class performances with assignment. Students suggested that live broadcasting activities take place at regular intervals, opening the comments section under the videos, conducting discussion board activities, establishing fast support systems, using alternative evaluation methods such as online testing and online presentations during the asynchronous online learning process.
\end{abstract}

Keywords: Distance education, asynchronous online learning, student experiences

\footnotetext{
${ }^{1}$ Ethics committee permissions for this study were obtained from Aksaray University with the decision dated 24.04.2020 and numbered 2020 / 03-11.

${ }^{2}$ Assist.Prof.Dr., Aksaray University, Faculty of Education, Department of Computer Education and Instructional Technologies, mucahitozturk@aksaray.edu.tr, ORCID ID: 0000-0003-4293-9086.
}

Received: 09.07.2020, Accepted: 13.02.2021 


\section{Öğrencilerin Pandemi Sürecinde Asenkron Çevrimiçi Öğrenme Deneyimleri: Kolaylıklar, Güçlükler, Öneriler}

Öz

$\mathrm{Bu}$ çalışma asenkron çevrimiçi öğrenme ortamında öğrencilerin deneyimlerini incelemiştir. Öğrenciler asenkron çevrimiçi öğrenme ortamını etkileşim, geribildirim, akademik ve teknik destek, aktif öğrenme ve değerlendirme açısından değerlendirmiştir. Çalışma eğitim fakültesinde öğrenim gören 28 öğrenci ile yürütülmüştür. Öğrenciler pandemi döneminde tüm derslere 9 hafta boyunca asenkron uzaktan eğitim ile devam etmiştir. Dönem sonunda öğrencilere görüşme formu e-posta ile gönderilmiştir. Çalışmanın sonunda asenkron çevrimiçi öğrenme sürecinde öğrencilerin öğretim üyesiyle iletişim problemi yaşamasalar da yüz yüze etkileşim eksikliği hissettikleri söylenebilir. Öğrenciler ihtiyaç duyduklarında destek alabilmişlerdir. Ancak anında geribildirim almakta sorun yaşamışlardır. Öğrencileri zaman ve mekan sınırı olmadan esnek öğrenme, kendi hızında sınırsız tekrar yaparak bağımsız öğrenme ve kendi öğrenme sürecini planlama fırsatı buldukları görülmüştür. Ancak arkadaşlarıyla birlikte grup çalışması yapamadıkları ve kendilerini sosyal olarak izole hissettikleri ortaya çıkmıştır. Öğrenciler ders içi performanslarının ödevlerle değerlendirilmesine karşı çıkmıştır. Öğrenciler asenkron çevrimiçi öğrenme sürecinde belirli aralıklarla canlı yayın etkinlikleri yapılmasını, videoların altına yorum bölümünün açılmasını, tartışma board etkinliklerinin yapılmasını, hızlı destek sistemlerinin kurulmasını, çevrimiçi test ve çevrimiçi sunum yapma gibi alternatif değerlendirme yollarının kullanılmasını önermiştir.

Anahtar Sözcükler: Uzaktan ĕgitim, asenkron çevrimiçi öğrenme, öğrenci deneyimleri 


\section{Introduction}

Distance education, which started with correspondence course, is carried out online in parallel with the development of information technologies. Higher education institutions have offered online courses and programs at undergraduate and postgraduate level by actively taking advantage of distance education that provides equal opportunities in education (Gibbings, Lidstone \& Bruce, 2015). In the countries that started to implement distance education within the framework of a certain strategy, the teaching process was not interrupted during the pandemic process we passed through. In this framework, distance education is seen as an important alternative when traditional education cannot be performed. With the spread of online technologies in distance education, concepts such as e-learning and online learning have gained importance (Sbaffi \& Bennett, 2019). Instructors and students actively use online learning environments with the ease of access to the Internet. Online learning environments allow students to access information flexibly, without limits of time and space, to do unlimited repetition and to plan their own learning (Fresen, 2018). On the other hand, there are disadvantages such as staff training, labor costs for preparing course content, students feel lonely and isolated, lack of face-to-face interaction (Muir, Milthorpe, Stone, Dyment, Freeman, \& Hopwood, 2019). These disadvantages are tried to be reduced by using the opportunities of internet technologies in the online learning environment. In this framework, synchronous and asynchronous communication ways are used (Beldarrain, 2006). In synchronous online learning, real-time communication is available, while in asynchronous online learning, instructors and students communicate at different times in line with their own planning. Asynchronous online learning is widely preferred (Jiang, 2017). As online learning becomes more common, more attention is paid to student satisfaction and engagement. In this context, students' perceptions and problems experienced should be determined and evaluated (Skelcher, Yang, Trespalacios \& Snelson, 2020). Although there are studies about student experiences in the online learning environment, there is a need for continuous research due to the changes in online technologies and student expectations (Shearer, Aldemir, Hitchcock, Resig, Driver \& Kohler 2019). In this study, the facilities provided by the asynchronous online learning environment and the challenges faced by the students were examined. Unlike similar researches, suggestions for solutions to challenges faced by students were also evaluated. 


\section{Asynchronous Online Learning}

There is no real-time communication between instructor and student in asynchronous online learning. The instructor usually shares the course contents such as videos and documents with the students through the learning management system. Students can access these contents at their own time and learn at their own pace by doing unlimited repetitions with the course content (Jiang, 2017). The instructor communicates with students through platforms such as discussion forum and e-mail. While the students take responsibility for their own learning, the instructor provides them with academic support during this process (Majeski, Stover \& Ronch, 2016). The instructor can give his students assignment. Students can also upload assignments to the system. Students have the opportunity to reflect on the concepts and facts of the lesson and to learn flexibly (Burns, Holford, \& Andronicos, 2020). Asynchronous online learning offers the opportunity to easily receive education to individuals who experience intensity in business and family life (Rose, 2016). Asynchronous online courses are often preferred by higher education institutions because of their flexibility in terms of time and space, and providing independent thinking opportunities for students learning at different speeds (Kim Yoon, Jo, \& Branch, 2018). Besides the many advantages of asynchronous online learning, it has some limitations. Lack of real-time and face-to-face interactions can cause students to feel lonely and have problems with commitment to online classes (Jiang, 2017; Strang, 2011). Problems such as lack of a classroom environment, technical support, decreased motivation and less interest in the lesson may arise (Nandi, Hamilton \& Harland, 2012; Potts, 2011; Schulte, 2011). Due to the continuous development of technologies used in asynchronous online learning and the changing needs, expectations and interests of students, student experiences in online learning environments attract attention as the subject of continuous study.

\section{Literature Review}

When the literature is analyzed, there are different studies about students' experiences in the asynchronous online learning environment. Shearer et al. (2020) examined the views of faculty and students in various online programs on the future of online learning. Focus group meetings were held with instructors and students. Interviews were conducted within the framework of the personal, social and content components of the online learning experience. At the end of the study, the researchers emphasized the need for personalized / adaptable learning systems 
Asynchronous Online Learning Experiences of Students in Pandemic Process: Facilities, Challenges,

Suggestions

in line with the needs and preferences of the students. In this context, the importance of environments where students can choose different types of content, have deep discussions and work with real-life problems has been expressed. Instant feedback and evaluation of their social, cognitive and emotional development have come to the fore in order to ensure the social presence of students. The instructor should give students autonomy, but follow and support them regularly. Future studies can examine students' online learning experience in terms of different dynamics. In addition, working with students studying in different programs at different universities will contribute to the field.

Berry and Hughes (2020) examined the online experiences of graduate students with the qualitative research method by comparing them with traditional face-to-face teaching. In the study, students' online learning experiences were evaluated in the context of work and life balance. It has emerged that online learning has advantages such as flexibility and autonomy against the limitations of isolation and time-lags.

Muir et al. (2019) tried to identify the factors affecting the participation of university students in the online learning environment. Students followed the courses asynchronously for one semester. They also participated in the discussion board and assignment events. During the study, feedback was received from students about their attendance status, and interviews were held with the students at the end of the study. Factors such as assessment, weekly workload, the instructor presence, work-life balance, appropriateness of learning tasks and interaction in the asynchronous online learning environment have been found to affect student participation. Researchers stated that studies to be conducted to determine the factors affecting students' online learning experiences and course participation will contribute to effective learning outcomes.

York, Yamagata-Lynch and Smaldino (2016) examined students' critical thinking ability regarding their own learning in an online instructional technology course. The students participated in asynchronous discussions. At the end of the study, it was revealed that giving students the opportunity to reflect themselves contributed to their thinking about their own learning. The study suggested that examining students' experiences and thoughts in the online environment may be effective in reducing the problems of students who have difficulty in transitioning from traditional to online environment. 
Lyons and Evans (2013) investigated the impact of online discussion forum activities on undergraduate students' satisfaction in a blended learning environment. At the end of the study, it was revealed that asynchronous online discussions increased students' satisfaction. Students were able to get support from their peers and give individual feedback via discussion boards. Potts (2011) examined the views of the students on the content creation process for sharing with peers in the online learning environment. Students generally viewed the preparation of materials for online learning positively. However, there are concerns such as workload, evaluation pressure, and difficulty of the material creation process. Careful examination of student-used content, group work and instructor attention can reduce these concerns.

Sullivan and Freishtat (2013) evaluated the experiences of graduate students in participating in online discussions in a blended course. Researchers investigated student-centered learning, group learning, problem-based learning, flexible learning, reflection, and student engagement by examining student experiences. The results of the study revealed that monitoring student experiences continuously will facilitate the course designs of the instructors and contribute to the determination of performance-related factors.

Students' online learning experiences were analyzed periodically through different studies. Researchers recommend continuous studies in this subject at a time when online technologies, students' expectations and interests change (Berry \& Hughes, 2020; Gómez-Rey, Barbera \& Navarro, 2016; Hambacher, Ginn \& Slater, 2018). In this study, differently from similar studies, students evaluated the online learning process, in which all courses were conducted asynchronously and they had not experienced before, within the framework of the theoretical knowledge they received in the Open and distance learning course. The students also suggested solutions to the challenges they expressed while evaluating. With these aspects, this study not only revealed the opportunities and challenges of the asynchronous online learning process, but also offered solutions from the students' perspective for future studies.

\section{Purpose of Study}

The aim of this study is to examine the experiences of students in the teaching process carried out with asynchronous online learning. The problems of the research are listed below.

1. What are the facilities of the asynchronous online learning process to students? 
2. What are the challenges students face during the asynchronous online learning process?

3. What are the students' suggestions regarding the online learning process?

\section{Methodology}

This study is a phenomenological study carried out with a qualitative research approach. Phenomological studies investigate perceptions, reactions and experiences against a particular phenomenon (Fraenkel, Wallen \& Hyun, 2012).

\section{Participants}

Participants consist of faculty of education English language education, Mathematics education, Music education, Preschool education, Guidance and psychological counseling, Classroom education, Social studies education, Turkish education departments, 28 university students (18-22 ages) studying in the 2nd grade. Participants were students who study the Open and distance learning course from faculty common courses and had not experienced online learning before. Open and distance learning course was took by 32 students. However, 28 students responded to the data collection form. Table 1 shows the number of students who filled the interview form.

Table 1

Participants

\begin{tabular}{lll}
\hline Departments & Male & Female \\
\hline English language education & 1 & 2 \\
Mathematics education & - & 1 \\
Music education & 3 & 2 \\
Preschool education, & 1 & 3 \\
Guidance and psychological counseling & 2 & 2 \\
Classroom education & 1 & 2 \\
Social studies education & 2 & 3 \\
Turkish education & 2 & 1 \\
\hline Total & 12 & 16 \\
\hline
\end{tabular}




\section{Data Collection Instruments}

An interview form was prepared to determine the students' asynchronous online learning experiences. The questions in the interview form were prepared within the framework of the Common Quality Indicators of Distance Education determined by Chaney et al. (2009) Although the researchers identified 15 indicators for the quality of distance education, different researchers combined some of these indicators and evaluated them (Sorensen \& Baylen, 2009; Zaharias \& Poylymenakou, 2009). In this context, it is aimed that students make detailed and objective evaluations within the framework of factors commonly used for online environments. In this study students' opinions were taken on the themes of Interaction, Feedback, Academic and Technical Support, Active Learning, Assessment. In the interview form, open-ended questions were asked to the students within the framework of the themes determined. The students wrote opinions about the facilities, challenges encountered and suggestions provided by the asynchronous online learning process under each theme title. For example, the following questions were asked under the theme of interaction. What are the advantages of the asynchronous online learning process in interacting with the instructor? What are the problems you encounter with the instructor in the process of online learning asynchronous? How can instructor and student interaction be achieved in the asynchronous online learning process? The positive and negative evaluations of the students regarding each theme were obtained. However, it was observed that students sometimes left blank if there was no positive or negative opinion in the theme asked.

\section{Data Collection Process}

Our world and our country go through a pandemic process. Therefore, distance education has started in our country. All courses have been given by distance education starting from the 6th week at the university where the study was conducted. The students continued their courses with asynchronous distance education for 9 weeks. Participating students also took elective Open and distance learning course this semester. The researcher conducted the Open and distance learning course in this study. The Open and distance learning course includes theoretical information about conceptual and theoretical structure, development, application methods and technologies of distance education. The students were expected to evaluate their 
asynchronous online learning experiences within the framework of the theoretical knowledge they learned in this course. Instructors uploaded at least one video lesson (1 lesson duration: $20 \mathrm{~min}$.) and one document to the learning management system every week in all courses. The learning management system enables activities such as discussion forum, online test, assignment as well as video and document activities. The students followed the courses whenever they wanted. The instructor reported and followed the students' activities in the learning management system. Assignment were given to students for midterm and final exams. Some instructors conducted online test and discussion forum activities on the system periodically. At the end of the study, the interview form was sent to the students via e-mail. Students were given one week to fill in the form. After the students filled the form, they sent it to the researcher by e-mail again. The students were asked to fill the form on a voluntary basis. While sending forms to 32 students, feedback was received from 28 students.

\section{Data Analysis}

The qualitative data collected at the end of the study were interpreted through descriptive analysis. Descriptive analysis is the evaluation of the data collected during the research by summarizing within the framework of previously determined themes. The descriptive analysis process was carried out in four stages (Yıldırım \& Şimşek, 2018).

1. Creating the framework for descriptive analysis: The researcher asked questions about Interaction, Feedback, Academic and Technical Support, Active Learning, Assessment themes in the interview form. The students evaluated the opportunities offered by the asynchronous learning process, the problems they encountered and their solution suggestions regarding each theme. Data analysis was carried out by grouping them under these themes as opportunities, challenges and suggestions.

2. Processing of data according to thematic framework: The data analysis was performed by two experts other than the researcher within the framework of phenomenological analysis principles suggested by Willing (2008). Experts processed the answers given by the students into the data analysis form. Students were coded as S1 ... S28. The data analysis form was prepared as a table in Microsoft Word program. While the experts 
entered the students' statements into the data analysis form, they did not consider the statements they thought were not related to the themes.

3. Description of findings: Experts have transformed students' expressions on themes into easy understandable and readable forms. Later, the experts compared the analysis tables they prepared and finalized the data.

4. Interpretation of the findings: Experts saved the summary information obtained as a result of the analysis and the statements of the students regarding this information on the data analysis form. While the researcher presented the summary knowledge as a table in the findings section within the framework of the problems of the research, he made quotations from the statements of the students.

After the researcher prepared the interview form and data analysis form, he received the opinions of two field experts and one language expert. The forms were finalized by making necessary changes within the framework of expert feedback. In this study, data analysis was performed by two experts in order to reduce researcher bias. The reliability of the data analysis was calculated using the reliability formula of Miles and Huberman (1994) $(($ reliability $=$ consensus $/($ consensus + disagreement $))$. When the data analysis of the experts were compared, it was found that it was $92 \%$ compatible and the data analysis was found to be reliable.

\section{Findings}

\section{Facilities Offered by the Asynchronous Online Learning Process}

\section{Interaction}

It was revealed that the students' interactions with the instructor are provided via e-mail, learning management system and messaging using WhatsApp. It was observed that the students 
Asynchronous Online Learning Experiences of Students in Pandemic Process: Facilities, Challenges, Suggestions

did not have communication problems with their instructors and friends. S4 expressed this situation as follows:

"I asked my questions via e-mail and system to my instructors. In some courses, our instructors contacted us via WhatsApp. Although some of our instructors answered our questions late, we did not have communication problems."

The students stated that the assignment, discussion board, and online test activities in some courses contributed positively to the interaction between the instructor and each other. S2 and S14 expressed this situation as follows:

"Some of our instructors took our ideas about the lesson with the discussion board activity. I answered the questions we asked. We had a quiz in some weeks. I had the opportunity to express myself with these activities."

"I contacted my instructors and friends to complete my assignments. I made voice conversations with my friends while sending e-mail to instructors."

Table 2 shows the facilities expressed by the students regarding the interactions in the asynchronous online learning environment and the number of students expressing these facilities.

Table 2

Facilities in the Context of Interaction

\begin{tabular}{ll}
\hline Facilities & Frequency \\
\hline Student-student interaction to complete assignments & 24 \\
Student-instructor interaction to complete assignments & 12 \\
Student-instructor interaction with discussion board activities & 10 \\
\hline
\end{tabular}

As shown in Table 2, it was revealed that students interacted with their peers and instructors to complete activities such as assignments and discussion forum. The majority of the students emphasized student-student interaction.

\section{Feedback}

Students stated that instructors mostly give feedback via e-mail. In some courses, it was revealed that WhatsApp groups were established and instructors gave feedback to their 
students. When they asked instructors questions, it was observed that they received answers, although there were sometimes delays. S13 and S15 explained this situation as follows:

"I mostly sent e-mails to my instructors via the system. I did not have any problems as all my instructors answered my messages. In addition, some of our instructors gave feedback through WhatsApp groups."

"I sent e-mails to the others while asking questions via WhatsApp to my instructors who had contact information. My instructors answered my questions via WhatsApp and e-mail."

Table 3 shows the facilities expressed by students about feedback in an asynchronous online learning environment and the number of students expressing these facilities.

Table 3

Facilities in the Context of Feedback

\begin{tabular}{ll}
\hline Facilities & Frequency \\
\hline Feedback via e-mail & 24 \\
Feedback via the learning management system & 18 \\
Feedback via WhatsApp & 14 \\
\hline
\end{tabular}

Students asked questions to the instructors via e-mail, the learning management system, and WhatsApp. Instructors gave feedback in whatever method the students reached them.

\section{Academic and Technical Support}

It was revealed that when students had problems, they got support from their peers first. If they could not solve the problem they faced, it was revealed that they reached the instructors. The students mostly got help from each other about the assignments given. They did not need much technical support for the use of the system. S23 and S28 expressed this situation as follows:

"When I needed help with the course, I mostly got support from my friend. Generally, I asked my instructors about their midterm and final assignments. I did not need technical support".

"I got support from my friends and instructors to complete the assignments. I often asked my instructors about assignments that would replace exams. While doing assignments, I was in constant contact with my friends." 
Table 4 shows the facilities expressed by students regarding academic and technical support in an asynchronous online learning environment and the number of students expressing these facilities.

Table 4

Facilities in the Context of Academic and Technical Support

\begin{tabular}{ll}
\hline Facilities & Frequency \\
\hline Getting academic support from peers & 24 \\
Getting academic support from instructors & 20 \\
Getting technical support from instructors & 2 \\
\hline
\end{tabular}

It was determined that the students needed academic support more and they got support from their peers and instructors. It turned out that they needed academic support to complete their assignments.

\section{Active Learning}

It was seen that students had the opportunity to study at their own pace and individually in an asynchronous online learning environment. It was revealed that the students were able to take notes comfortably while watching videos, do research about assignment, and study with support from their peers or instructors. S4 and S9 explained this situation as follows:

"I took notes while watching videos and watched the places I did not understand again. While preparing assignment, I studied with the help of my friend."

"When I didn't understand the course videos, I had the opportunity to watch them again. Also, having the opportunity to pause while watching videos enabled me to take notes comfortably."

It was revealed that sharing course notes next to the videos of the instructor supports students' learning and they use these notes while preparing assignment. S26 and S27 explained this situation as follows:

"It was very useful to have course notes besides videos. I was reviewed these notes as I prepared the final assignments."

"Having opportunities such as taking notes, following course notes and doing research while watching the courses made it easier for me to learn." 
Asynchronous online learning has been seen to give students the opportunity to develop their own learning strategies. The students stated that it is very advantageous to have the opportunity to access the course content without time and space limits. It gave students the opportunity to flexibly learn, to do limitless repetition and to organize their own learning environment. S10 and S22 explained this situation as follows:

"In the videos, I returned to the places I did not understand and watched. I noted the important parts. I watched videos from my phone when I was not at home. When I went to the village, I continued to watch the video courses. Accessing the course contents from anywhere gave us a lot of flexibility."

"Since I could follow the lectures on a computer and mobile phone, I was able to watch videos when I was not at home."

Table 5 shows the activities that students do within the scope of active learning and the number of students expressing these activities in an asynchronous online learning environment.

Table 5

Facilities in the Context of Active Learning

\begin{tabular}{ll}
\hline Facilities & Frequency \\
\hline Practicing with assignments & 20 \\
Learning by watching videos and studying with course notes & 17 \\
Flexible learning in terms of time and space & 14 \\
Learning at own pace & 10 \\
Taking notes easily while watching the course & 7 \\
\hline
\end{tabular}

\section{Assessment}

Students stated that evaluation in an asynchronous online learning environment is a difficult process. It was seen that assignment, which is the method used in evaluating students, is not sufficient for students.

\section{Challenges Encountered in the Asynchronous Online Learning Process}

\section{Interaction}


Asynchronous Online Learning Experiences of Students in Pandemic Process: Facilities, Challenges, Suggestions

Although most of the students do not have communication problems with instructors, they stated that there is no interaction like face-to-face learning environment and this situation affects them negatively. S9 explained the interaction problems as follows:

"Although we were in constant communication with our instructors, I felt the lack of face-to-face interaction. Since I got used to listening courses in a normal classroom environment, listening to courses remotely affected me negatively."

Some of the students have been unable to follow the courses due to the technical problems they had on the internet connection and had a communication disruption with the instructor. S5 and S19 expressed this situation as follows:

"Sometimes I disconnected my internet connection because of my stay in the village. I used the mobile internet to solve this situation, but my internet quota expired very quickly. Therefore, sometimes I could not follow the courses regularly."

"When my computer broke down, I watched the courses on my mobile phone, but I did not get much efficiency and had difficulty understanding the course content."

Table 6 shows the problems that students express about interactions in an asynchronous online learning environment and the number of students expressing these problems.

Table 6

Challenges in the Context of Interaction

\begin{tabular}{ll}
\hline Challenges & Frequency \\
\hline Lack of face-to-face interaction & 22 \\
Not being able to access course content due to technical problems & 7 \\
\hline
\end{tabular}

It was determined that students need face-to-face interaction and they lack student-content interaction due to problems such as internet connection and disruption of the devices used.

\section{Feedback}

It was revealed that the students complained about the feedback that some instructor responded late. S17 explained this situation as follows: "All my instructors answered the questions I asked. However, some of my instructors answered late. It would be nice if I had quicker help on the issues I was having problems with". Table 7 shows the problems students expressed 
about feedback in an asynchronous online learning environment and the number of students expressing these problems.

Table 7

Challenges in the Context of Feedback

\begin{tabular}{ll}
\hline Challenges & Frequency \\
\hline Lack of instant feedback & 10 \\
\hline
\end{tabular}

While the students stated that they got answers to all the questions they asked, it was determined that some students could not get instant feedback.

\section{Academic and technical support}

It was seen that the students had problems with the assignment substitutes for the midterm and final exam. They stated that they had difficulty in preparing some assignment and being away from the instructor and their peers had a negative effect on getting support. S6 and S20 explained this situation as follows:

"In preparing to assignment, I needed support on some issues. I couldn't find the necessary information on the internet. I asked my friends or instructors, but there were times when I couldn't solve my problems. I had a hard time preparing and understanding some assignment. If I were in the normal class, I would get help more easily."

"As we were not in the same environment with our instructors, I had difficulty solving my problems in practical courses. Although there are advantages of distance education, I think that being far from each other prevents getting support quickly."

Table 8 shows the problems students have expressed regarding academic and technical support in an asynchronous online learning environment and the number of students expressing these problems.

Table 8

Challenges in the Context of Academic and Technical Support

\begin{tabular}{ll}
\hline Challenges & Frequency \\
\hline Not getting enough support for assignments & 11 \\
Being away from peers and instructors & 9 \\
\hline
\end{tabular}


It was revealed that some students had problems while getting support because they were in different environments with their instructors and peers.

\section{Active Learning}

It was revealed that the students had planning problems in following the courses regularly, they could not do much group work, they had difficulty focusing on the lesson, and they got bored because of the high duration of the video lessons in some courses. S21 and S25 expressed this situation as follows:

"I couldn't watch the lessons on time. There was a comfortable atmosphere at home and this caused my attention to be easily distracted".

"In some courses the videos were long so I got bored quickly. The courses we had the opportunity to work with our friends were very fun. However, we could not find this opportunity in most of the courses".

It was revealed that the students are distant from each other in the asynchronous online learning environment, making them feel lonely. In addition, some of the students emphasized the negative impact of the pandemic process we went through. S8 explained this situation as follows:

"With our transition to distance education, I followed the courses from home. Not being able to be in the same environment with my friends and instructors has affected me badly. I feel lonely. In addition, the pandemic process we went through made me feel worse."

Table 9 shows the problems that students express about active learning in an asynchronous online learning environment and the number of students expressing these problems.

Table 9

Challenges in the Context of Active Learning

\begin{tabular}{ll}
\hline Challenges & Frequency \\
\hline Not being able to follow the courses regularly & 20 \\
Being unable to study in groups & 10 \\
Long duration of course videos & 9 \\
Feeling lonely & 8 \\
\hline
\end{tabular}


While it was determined that most of the students could not follow the course videos regularly, it was revealed that some of the students were dissatisfied with being unable to study with their friends and the duration of the videos was long duration and they felt lonely.

\section{Assessment}

It was seen that the students thought that the assignments replacing the midterm and final exams were not very efficient. They expressed problems such as the degree of difficulty of the assignment and the inability to access the materials required for the preparation of these assignment. In addition, students stated that exam performances should not be evaluated only with assignment and that they had problems in preparing assignment in some practical courses. S19 and S24 expressed this situation as follows:

"Although evaluation with assignment is appropriate in our situation, I had a hard time preparing some assignment. As a music educator, I do not find it very correct to evaluate practical courses with assignment (Choir, individual instrument etc.)."

"I ran into trouble as there was a lack of resources and support to complete some assignments.”

Table 10 shows the problems that students expressed regarding assessment in an asynchronous online learning environment and the number of students expressing these problems.

Table 10

Challenges in the Context of Assessment

\begin{tabular}{ll}
\hline Challenges & Frequency \\
\hline Difficulty preparing some assignments & 10 \\
Evaluation of practical courses with assignments. & 5 \\
\hline
\end{tabular}

\section{Suggestions for Asynchronous Online Learning Process}

\section{Interaction}

Although the students have a lack of face-to-face interaction during the asynchronous online learning process, they stated that this situation is natural but their interactions can be increased. S6 and S23 explained its suggestions for increasing interaction as follows: 
"If a comment section is added under the videos, we can immediately ask questions about the place we do not understand. Discussion boards that we do in some courses can be done in all courses provided that they are not very frequent."

"If live broadcasts are made at regular intervals, we can interact directly with the instructor, ask questions and get answers immediately. If quizzes done in some courses are done in all courses, this may enable us to see the places we do not understand. "

Table 11 shows the suggestions expressed by students about interaction in an asynchronous online learning environment and the number of students expressing these suggestions.

Table 11

Suggestions in the Context of Interaction

\begin{tabular}{ll}
\hline Suggestions & Frequency \\
\hline Live broadcast activities should be done. & 16 \\
Comments section should be added under videos & 11 \\
Discussion board activities should be done. & 10 \\
Online test activities should be done. & 6 \\
\hline
\end{tabular}

For the most effective interaction in an asynchronous online learning environment, students suggested that mostly live broadcasting activities, adding a comment section under video courses, and doing different activities such as discussion board and online test in all courses.

\section{Feedback}

Students brought suggestions that a live chat system can be established or WhatsApp groups can be used in all courses against the problem of not getting instant feedback in some courses. S18 explained this situation as follows: "Live chat system can be installed to get answers from our instructors faster or communication via WhatsApp can be used in all courses as we did in some courses". Table 12 shows the suggestions of students about feedback in an asynchronous online learning environment and the number of students expressing these suggestions.

Table 12

Suggestions in the Context of Feedback

\begin{tabular}{ll}
\hline Suggestions & Frequency \\
\hline Live chat system should be established & 14 \\
WhatsApp group should be established in all courses & 13 \\
\hline
\end{tabular}




\section{Academic and Technical Support}

The students stated that they had problems in preparing the assignment given in some courses, they could be given assignment easier and they should get quick support. S5 and S16 expressed this situation as follows:

"When we need help with assignment, systems can be established where we can reach our instructors faster. I had a hard time preparing some assignment. Our instructors can give assignments more understandable and easy."

"I had a hard time doing assignment in some classes. I think I will need less support if easier assignments are given in these courses."

Table 13 shows the suggestions that students express regarding academic and technical support in an asynchronous online learning environment and the number of students expressing these suggestions.

Table 13

Suggestions in the Context of Academic and Technical Support

\begin{tabular}{ll}
\hline Suggestions & Frequency \\
\hline Quick support system should be established & 14 \\
Easier assignments should be given & 13 \\
\hline
\end{tabular}

Since the students had difficulties in doing their assignment, they suggested establishing a fast support system and assigning them easy tasks.

\section{Active Learning}

Students made suggestions about working with more peers in the learning process, shorter duration of videos, and that instructors should make more effective presentations. S1 and S7 listed theirs recommendations for active learning as follows:

"My instructors can give assignment that I can work with my friends. Shorter and more effective courses can be prepared instead of very long videos. Audio and video quality were poor in some videos. Our instructors should make videos with better sound and image quality." 
Asynchronous Online Learning Experiences of Students in Pandemic Process: Facilities, Challenges, Suggestions

"I was very bored with some of our instructors lecturing. Instructors should present the course more fun and effective and should not make long duration videos.

Some of the students stated that giving an opportunity to present online can increase their motivation and provide more active participation to the course because the asynchronous online learning environment makes them feel lonely. S16 and S25 expressed this situation as follows:

"I felt lonely because we are separate from our friends and instructors in distance education. We made a presentation in one of our courses. It was a great experience for me. In other courses, online presentations can be made."

"I got bored quickly because we were far away from our friends in distance education. For this reason, we can be given the opportunity to make a presentation that will make us feel like in the classroom."

Table 14 shows the suggestions of students about active learning in an asynchronous online learning environment and the number of students expressing these suggestions.

Table 14

Suggestions in the Context of Active Learning

\begin{tabular}{ll}
\hline Suggestions & Frequency \\
\hline Students should be given the opportunity to study with their peers & 13 \\
Instructors should create shorter videos & 8 \\
Courses should be presented more effectively & 8 \\
Students should be given the opportunity to present online & 7 \\
Better quality videos should be prepared in terms of sound and image & 6 \\
\hline
\end{tabular}

The students made different suggestions for asynchronous online environments such as collaborative work, preparation of short duration and high definition video courses and online presentations.

\section{Assessment}

Students emphasized the need to use different assessment tools such as online testing and online presentations in addition to assignments during the asynchronous online learning process. S8 and S17 expressed this situation as follows:

"In some courses, our instructors made online tests. In other courses, online tests can be done and evaluated together with assignment." 
"In practical courses, online presentations can be made through live broadcasts, as we do in some courses."

Table 15 shows the suggestions that students express regarding assessment in an asynchronous online learning environment and the number of students expressing these suggestions.

Table 15.

Suggestions in the Context of Assessment

\begin{tabular}{ll}
\hline Suggestions & Frequency \\
\hline Alternative assessment methods should be used & 20 \\
\hline
\end{tabular}

Students suggested that the assessment tools should be diversified due to the problems they experienced in order to complete the assignment in some courses.

\section{Discussion and Conclusion}

In this study, students shared their experiences on interaction, feedback, academic and technical support, active learning and assessment themes in an asynchronous online learning environment. The interaction of students with instructors and peers was provided through instant messaging and discussion activities in some courses. The assignments assigned to the students increased their interactions with their peers and instructors. Asynchronous online learning has been observed that students can interact with instructors and peers through different platforms and have no communication problems. Muir et al. (2019) found that working together with assignments and discussion boards in the online learning environment increases the interaction and engagement of students with each other. In an asynchronous online learning environment, students and instructors communicate at different times. The students stated that this situation provides flexibility in terms of time and space, but they have limitations in terms of interaction. Although the students did not experience communication problems, they felt the lack of face-to-face interaction. The students considered that performing live broadcasting activities at certain intervals would give an opportunity to interact directly with the instructor. In addition, it has been found that adding comments section to the videos, performing online test and discussion board activities can enable students to see their shortcomings and increase their interaction with their instructors and peers. Some students have 
Asynchronous Online Learning Experiences of Students in Pandemic Process: Facilities, Challenges,

Suggestions

problems such as the disconnection of the internet and the malfunction of the devices they use while accessing the learning management system. The students did not make any suggestions regarding these problems that occurred outside of their own initiative.

Instructors gave feedback to the students via e-mail, learning management system and WhatsApp groups. They answered questions from discussion boards in some courses. It was revealed that the students had no problem in getting feedback. Lyons and Evans (2013) found that discussion boards and individual feedback in asynchronous online learning contributed positively to students' learning experiences and satisfaction. It is seen that students have problems in the timing of feedback. In some courses, it was revealed that students were not able to get instant answers to the questions they asked to their instructors and they were uncomfortable with this situation. Students suggested that live chat systems can be installed or WhatsApp groups can be used in all courses. It turns out that answering the questions asked by students in an asynchronous online learning environment is not enough alone and instant feedback is very important.

It can be said that students mostly got academic support regarding their assignment. Students primarily preferred peer support. If they couldn't solve their problems, they got support from the instructor. Shearer et al. (2020), in his study examining the experiences of students and instructors regarding the future of online learning, revealed the importance of leaving students autonomous in asynchronous online learning, but constantly supporting them and their contribution to their social presence. A small number of students needed technical support from instructors. The ease of use of asynchronous online learning systems ensured that students do not need too much technical support. It was observed that the students had problems about assignment because of being able to get fast and continuous support when they needed and being in a separate environment from the instructors and their peers. Regarding this problem, students suggested that rapid support systems can be established and the assignments that are easy to complete. Students did not need much technical support. It was found out that it is important to set up live support systems for the instructor to give immediate feedback in the asynchronous online learning environment. In this direction, students can quickly solve their problems in practical courses that they need more support. 
Asynchronous online learning environment gave students the opportunity to learn at their own pace, to do limitless repetitions, to organize their own learning environment and to study with assignment, to learn independently from time and space. In addition, students were able to take notes more easily with the start and stop feature while watching videos. In this framework, individual and flexible learning activities can be done. Sullivan and Richard (2013) found that providing students with flexible learning, group working and problem-based learning opportunities is important and will increase student engagement in an asynchronous online learning environment. While the students had difficulty in planning their own learning process, they could not follow the courses regularly. The students' being in a different environment from each other caused them to feel lonely and unable to study together. In addition, it was evaluated that the length of the videos was boring for some students. It has been revealed that students can be given assignment that they can work with their peers, online presentations can be made and video courses can be prepared more interactive and high quality.

It was determined that the students had various problems regarding the assessment process. While the students opposed the evaluation of their performance only by giving assignment, they suggested alternative evaluation methods. Trenholm, Alcock and Robinson (2015) emphasized the use of various tools together in the assessment of students in an asynchronous online learning environment. In the asynchronous online learning environment, it has been revealed that different data collection tools such as online tests and online presentations should be taken into consideration.

As a result, student-student interaction came to the fore in the asynchronous online learning process. On the other hand, although students do not have communication problems, they feel the lack of face-to-face interaction, so live chat activities should be made using online technologies. Since the students mostly preferred e-mail as the communication method, the instructors gave feedback in the same way. While this situation causes students not to receive instant feedback, WhatsApp etc. systems where they can get feedback faster can be used. Students mostly received academic support from each other regarding the tasks assigned to them, but they need more support, especially for practical courses, due to their away from each other. While asynchronous online learning provides students with opportunities such as learning at their own pace, working with different course contents, flexible learning, students have problems such as not being able to make a regular learning program, not being able to 
Asynchronous Online Learning Experiences of Students in Pandemic Process: Facilities, Challenges,

Suggestions

work with their peers and feeling lonely. Students should be given the opportunity to work collaboratively and instructors should present courses more effectively. In addition, students should evaluate not only with assignments but also through alternative means such as online testing and online presentations. This study was conducted in the period when students who continue traditional face-to-face teaching rapidly transition to asynchronous online learning process due to pandemic. Instead of associating asynchronous online learning with the pandemic, the students evaluated it in relation to the technologies used, instructors and course content. In this context, although the students stated that they were physically and psychologically affected by the pandemic, they did not evaluate the positive or negative effect of this situation on the asynchronous online learning process.

\section{Suggestions}

In this study, the facilities of the asynchronous online learning process, the challenges faced by the students and their suggestions regarding these problems were evaluated. In future studies, student experiences can be examined in the asynchronous online learning process by making arrangements within the framework of problems and suggestions expressed by students. In addition to the experiences of the students, the opinions of the instructors can also be evaluated together. In this study, the opinions of the students about the asynchronous online learning environment were evaluated with the qualitative data obtained from the interview form. Along with these data, quantitative data regarding the activities of students in the learning management system should also be taken into account. Student experiences regarding synchronous online learning environments should be analyzed and comparisons should be made with asynchronous online learning environment.

\section{Statements of Ethics and Conflict of Interest}

"I, as the Corresponding Author, declare and undertake that in the study titled as “Asynchronous Online Learning Experiences of Students in Pandemic Process: Facilities, Challenges, Suggestions", scientific, ethical and citation rules were followed; Turkish Online Journal of Qualitative Inquiry Journal Editorial Board has no responsibility for all ethical violations to be encountered, that all responsibility belongs to the author/s and that this study has not been sent to any other academic publication platform for evaluation." 


\section{References}

Beldarrain, Y. (2006). Distance education trends: Integrating new technologies to foster student interaction and collaboration. Distance education, 27 (2), 139-153.

Berry, G. R., \& Hughes, H. (2020). Integrating Work-Life Balance with 24/7 Information and Communication Technologies: The Experience of Adult: Students With Online Learning. American Journal of Distance Education, 34 (2).

Burns, A., Holford, P., \& Andronicos, N. (2020). Enhancing understanding of foundation concepts in first year university STEM: evaluation of an asynchronous online interactive lesson. Interactive Learning Environments, 1-13.

Chaney, B. H., Eddy, J. M., Dorman, S. M., Glessner, L. L., Green, B. L., \& Lara-Alecio, R. (2009). A primer on quality indicators of distance education. Health promotion practice, 10(2), 222-231.

Fraenkel, J. R., Wallen, N. E., \& Hyun, H. H. (2012). How to design and evaluate research in education eight edition. McGraw-Hill, New York.

Fresen, J. W. (2018). Embracing distance edeucation in a blended learning model: Challenges and prospects. Distance education, 39(2), 224-240.

Gibbings, P., Lidstone, J., \& Bruce, C. (2015). Students' experience of problem-based learning in virtual space. Higher Education Research \& Development, 34(1), 74-88.

Gómez-Rey, P., Barbera, E., \& Fernández-Navarro, F. (2016). Measuring teachers and learners' perceptions of the quality of their online learning experience. Distance Education, 37(2), 146-163.

Hambacher, E., Ginn, K., \& Slater, K. (2018). Letting students lead: Preservice teachers' experiences of learning in online discussions. Journal of Digital Learning in Teacher Education, 34(3), 151-165.

Jiang, W. (2017). Interdependence of roles, role rotation, and sense of community in an online course. Distance Education, 38(1), 84-105.

Kim, D., Yoon, M., Jo, I. H., \& Branch, R. M. (2018). Learning analytics to support selfregulated learning in asynchronous online courses: A case study at a women's university in South Korea. Computers \& Education, 127, 233-251.

Lyons, T., \& Evans, M. M. (2013). Blended learning to increase student satisfaction: an exploratory study. Internet reference services quarterly, 18(1), 43-53. 
Majeski, R. A., Stover, M., \& Ronch, J. (2016). Making asynchronous online learning more learner-oriented: An integrated conceptual model with applications for course design and instruction. Educational Gerontology, 42(2), 109-119.

Miles, M. B., \& Huberman, A. M. (1994). An expanded sourcebook qualitative data analysis. Sage Publications, London.

Muir, T., Milthorpe, N., Stone, C., Dyment, J., Freeman, E., \& Hopwood, B. (2019). Chronicling engagement: students' experience of online learning over time. Distance Education, 40(2), 262-277.

Nandi, D., Hamilton, M., \& Harland, J. (2012). Evaluating the quality of interaction in asynchronous discussion forums in fully online courses. Distance education, 33(1), 530 .

Potts, H. W. (2011). Student experiences of creating and sharing material in online learning. Medical Teacher, 33(11).

Rose, E. (2016). Reflection in asynchronous online postsecondary courses: a reflective review of the literature. Reflective Practice, 17(6), 779-791.

Sbaffi, L., \& Bennett, J. (2019). Postgraduate students' experience of a jointly-taught, distance learning degree: the example of a Russell Group university. Journal of Higher Education Policy and Management, 41(6), 600-618.

Schulte, M. (2011). The foundations of technology distance education: A review of the literature to 2001. The Journal of Continuing Higher Education, 59(1), 34-44.

Shearer, R. L., Aldemir, T., Hitchcock, J., Resig, J., Driver, J., \& Kohler, M. (2020). What students want: A vision of a future online learning experience grounded in distance education theory. American Journal of Distance Education, 34(1), 36-52.

Skelcher, S., Yang, D., Trespalacios, J., \& Snelson, C. (2020). Connecting online students to their higher learning institution. Distance Education, 41(1), 128-147.

Sorensen, C. K., \& Baylen, D. M. (2009). Learning online: Adapting the seven principles of good practice to a Web-based instructional environment. In A. Orellana, T. L. Hudgins, \& M. Samonson (Eds.), The perfect online course: Best practices for designing and teaching (pp. 69-86). Charlotte, NY: Information Age Publishing.

Strang, K. D. (2011). Asynchronous knowledge sharing and conversation interaction impact on grade in an online business course. Journal of Education for Business, 86(4), 223233. 
Sullivan, T. M., \& Freishtat, R. (2013). Extending learning beyond the classroom: Graduate student experiences of online discussions in a hybrid course. The Journal of Continuing Higher Education, 61(1), 12-22.

Trenholm, S., Alcock, L., \& Robinson, C. (2015). An investigation of assessment and feedback practices in fully asynchronous online undergraduate mathematics courses. International Journal of Mathematical Education in Science and Technology, 46(8), 1197-1221.

Willig C. 2008. Introducing qualitative research in psychology. Maidenhead: Open University Press.

Yıldırım, A., \& Şimşek, H. (2008). Sosyal Bilimlerde Nitel Araştırma Yöntemleri (11. Baskı). Ankara: Seçkin Yayıncılık.

York, C. S., Yamagata-Lynch, L. C., \& Smaldino, S. E. (2016). Adult reflection in a graduatelevel online distance education course. Reflective Practice, 17(1), 40-58.

Zaharias, P., \& Poylymenakou, A. (2009). Developing a usability evaluation method for elearning applications: Beyond functional usability. Intl. Journal of Human-Computer Interaction, 25(1), 75-98. 